\title{
APPLICATION OF DATA ENVELOPMENT ANALYSIS (DEA) ON THE TECHNICAL EFFICIENCY OF ORGANIC SWAMP CABBAGE FARMING AT MUTIARA FARM, PAGELARAN VILLAGE, PAGELARAN SUB-DISTRICT, MALANG REGENCY, EAST JAVA
}

\author{
Sari Perwita ${ }^{1 *}$, Rini Dwiastuti ${ }^{2}$, Nuhfil Hanani ${ }^{2}$ \\ ${ }^{1}$ Master's Degree, Post Graduation Program Faculty of Agriculture, University of Brawijaya, Indonesia \\ ${ }^{2}$ Economic Agriculture, University of Brawijaya, Indonesia \\ *corresponding author: sari_fp@widyakarya.ac.id
}

\begin{abstract}
The use of inputs in producing output is an important thing to be considered in the production process. Efficiency is a measure that shows how well resources are used in the production process. This study aims to analyze: 1) technical efficiency of the amount of polybags, seeds, organic fertilizer, and working hours used in organic swamp cabbage farming at Mutiara Farm, Pagelaran Village; 2) scale efficiency level of each farmer; 3) adjustment of inputs used; 4) peers; and 5) factors that affect technical efficiency. The method used to analyze technical efficiency, scale efficiency, input usage settings, and peers is Data Envelopment Analysis (DEA). Tobit Regression is used to analyze the factors that influence efficiency level. The results showed that the use of production factors was not yet full-efficient. Average efficiency is $94 \%$. Five farmers have scale efficiency and operate in constant return to scale. Twenty-seven farmers have scale inefficiency, which consists of 17 farmers operating in increasing returns to scale and 10 farmers operating in decreasing returns to scale. The average reduction in polybag inputs is 64 , seeds are 2,743 seeds, fertilizer is $187 \mathrm{~kg}$, and working hours are 16 hours. Full efficient farmers with the highest number of peers are the 27th farmer, namely as many as 19 peers. Age and farming experience affect the value of technical efficiency. Age variable has a more dominant influence than farming experience.
\end{abstract}

Keywords: Data Envelopment Analysis, Technical Efficiency, Tobit Regression

http://dx.doi.org/10.21776/ub.agrise.2020.020.1.7

Received 2 August 2019

Accepted 17 December 2019

Available online 31 January 2020

\section{INTRODUCTION}

Vegetables are a food supplement for staple foods that are rich in nutrients of protein, vitamins and minerals. The average increase in household expenditure for vegetables in 2016 from 2015 was $26.09 \%$, while the growth of vegetable production was $4.5 \%$. Based on the differences in these two numbers, there is the potential to fulfill household consumption by planning and implementing vegetable farming well. Data of Badan Pusat Statistik (2017) shows that Indonesia until 2016 still imported a number of vegetables to meet food needs.

Enhancement of public awareness toward healthy food consumption causes the increase of consumer preferences for organic vegetables. The government has launched the 2010 Go Organic policy as an effort to develop organic agriculture

CITATION: Perwita S., Dwiastuti R., Hanani N. (2020). Application of data Envelopment Analysis (DEA) on the Technical Efficiency of Organic Swamp Cabbage farming at Mutiara Farm, Pagelaran Village, Pagelaran Sub-District, Malang Regency, East Java. Agricultural Socio-Economics Journal, 20(1), 45-56 DOI: http://dx.doi.org/10.21776/ub.agrise.2020.020.1.7 
with one of the strategies is to promote organic agriculture to consumers, farmers, market participants, and the community.

The factors that cause low organic agricultural production are, among others, internal and external constraints of farming. Internal factors include management of production factors used, level of farmer knowledge, and the level of farmer ability to use production factors efficiently. External factors include limited land availability for productive agriculture, competition for the use of land resources with other commodities, continuity of availability of factors of production, and natural conditions (Astuti, et. al., 2013 and Kalauw, et. al., 2015).

The Ministry of Agriculture has initiated the optimization of house yard use through the concept of Rumah Pangan Lestari (RPL). Rumah Pangan Lestari is a residents house who cultivate the yard intensively to be used with a variety of local resources wisely which ensures the continuity of the supply of quality and varied household foodstuffs. Development of RPL on a broad scale, based on subvillages, villages, or other areas that might be called the Kawasan Rumah Pangan Lestari (KRPL). To get optimal results, the use of the yard also requires attention with regards to crop cultivation.

The selection of organic vegetables developed in the yard is based on the consideration that the planting process up to harvesting, is easy and safe, healthier vegetables, and environmentally friendly. With the use of the yard through the cultivation of organic vegetables, women farmers can get involved, participate, and play an active role in these activities (Ariyanti et. al., 2013).

Farmer women are adult and young rural women. According to Sajogyo in Sembiring (2008), the involvement of women farmers in farming activities also determines the success of farming and household activities. Widyawati and Rizal (2015) states that the role of farmers women in organic vegetable farming includes various aspects, especially in making decisions in every aspect of farming and outpouring of time. Farmer women also acted as farm managers because the decision to determine planting time, types of plants and so on were done by farmers women.

One of vegetables that can be cultivated in the yard is swamp cabbage (Ipomea reptans Poir) which is commonly used to fulfill daily needs, much in demand by the public, and the price is relatively affordable to various groups of people. Swamp cabbage contains vitamin A, vitamin C, complex vitamin B, calcium, phosphorus, iron, carotenoids, and lutein with the efficacy of preventing anemia and diabetes, improving brain quality, maintaining heart health, maintaining the immune system, maintaining eye health, and reduce cholesterol (Widyawati and Rizal, 2015).

Pagelaran Village is one of ten vilaages in Pagelaran Sub-district, Malang Regency. Most of the farming are paddy, corn, sugar cane and thorny palm. The agricultural development system in Pagelaran Sub-district is directed at empowering farmers/farmer groups through cooperation, among others, with the agricultural department, counseling biard, and other farmer groups.

Two farmer women group that incorporated in Mutiara Farm respond to the program and establish relationships with Gabungan Kelompok Tani (Gapoktan) Mulyo Santoso and C.V. Kurnia Kitri Farm Malang. The programs that have been held by these partners are RPL counseling, training, coaching, and mentoring, especially to women farmers about organic vegetables farming in the house yard.

The use of inputs in producing output is an important thing that needs to be considered in the production process. Efficiency is a measure that shows how well resources are used to produce output. Efficiency is a process characteristic that measures performance or actual performance of resources relative to the standards set (Coelli, et al., 2005). Efforts to increase farm production through production efficiency are one of the choices that can be made. Attention to the efficiency of farming production has an impact that farmers are able to use production inputs in accordance with the provisions to obtain optimal production results.

Data Envelopment Analysis (DEA) is a nonparametric method used to assess the relative efficiency of a set decision making units (DMU) based on linear programming applications. This analysis can be used to determine the level of efficiency of input use in farming. Efficiency scores for each Decision Making Unit/DMU (farmers) are obtained by calculating DEA using a variable return to scale (VRS) approach and input-oriented. DMUs are declared efficient if they have a score of 1 , which means they are able to combine the use of inputs efficiently to achieve the specified output. 
DEA results also revealed scale efficiency of each farmer and categorized into scale efficient and scale inefficient groups. Scale efficiency value is obtained by dividing the CRSTE value by the value of VRSTE. Scores equal to 1 state scale efficient where farmers operate on constant return to scale. Scores not equal to 1 state scale inefficient and farmers operate in increasing return to scale or decreasing return to scale.

The amount of input reduction is indicated by the results of the radial movement and slack movement. The target input is obtained by subtracting the actual input with the result of a radial movement and slack movement. The use of the number of inputs according to the target input results in technical efficiency. Farmers who have achieved efficiency can be refered as a reference for farmers who have not achieved efficiency. The farmer is stated as a peer for other farmers. Technical efficiency can be achieved by referring to the amount of input used by the peer.

The value of technical efficiency achieved by farmers is influenced by several factors. The study conducted by Binam et al. (2005) identified the factors of education level, age, number of family members, participation in farmer groups, and land size in corn and bean farmers. The research is also in line with research conducted by Lawalata, Darwanto, and Hartono (2015) on shallot farming.

Tobit Regression Model is used to analyze the factors that influence the efficiency level of input used. This model uses a dependent variable that is censored or limited or intentionally limited. Parameter values are estimated by the Maximum Likelihood Method. The use of this method overcomes the deficiencies of multiple regression analysis tools by using the Ordinary Least Square (OLS) method that result in biased and inconsistent parameter estimates. Based on these explanations, this study examines the level of technical efficiency of the use of production factors in organic swamp cabbage farming. The level of efficiency is then assessed based on the factors that influence it.

\section{RESEARCH METHODS}

The location of the study was determined intentionally at Mutiara Farm, Pagelaran Village, Pagelaran Subdistrict, Malang Regency. The selection of research sites was based on the consideration that farmers' women actively cultivate organic vegetables in the yard under guidance of Gabungan Kelompok Tani (Gapoktan) Mulyo Santoso and C.V. Kurnia Kitri Ayu Farm, Malang City. The study was conducted in MayAugust 2018.

The sampling method used is the saturated sampling method (census sampling) where all members of the population are sampled because the population is relatively small. Respondents used in this study were 32 respondents. Several other parties were involved in this study as supporting the completeness of the data and discussion, namely Management of Gapoktan Mulyo Santoso and C.V. Kurnia Kitri Ayu Farm, Malang City.

Data collection methods used in this study were interviews, focus group discussion (FGD), observation and filling in questionnaires. Interviews were conducted with several informants, namely farmers' women, Mutiara Farm coaches, CV Kurnia Kitri Ayu Farm and Gapoktan Mulyo Santoso. Focus group discussions are conducted to obtain more in-depth information by exploring ideas and opinions clearly and in detail, which includes difficulties, obstacles, and solutions in farming. Observation is done by participant observation. Researcher actively participates by getting involved in all activities to understand all activities related to farming. The questionnaire is filled independently by the respondent which includes the identity of the respondent, the amount of production, and the number of production factors used.

Data analysis methods used in this study are Data Envelopment Analysis (DEA) and Tobit Regression.

\section{Data Envelopment Analysis (DEA)}

The amount use of polybags, seeds, organic fertilizer, and working hours was analyzed by using the Data Envelopment Analysis (DEA) Variable Returns to Scale (DEA VRS) assumption. This model assumes that the ratio between the addition of input and output is not the same. The selection of the assumption is based on Coelli, et al. (2005) with the consideration that farming does not operate at an optimal scale because of imperfect competition and limited production factors used. With this assumption, it is possible to calculate technical efficiency (TE) without scale efficiency (SE). The value of technical efficiency is calculated based on input oriented (minimization of input) and produces amount of input reduction with the output level remaining constant. The equation model used is as follows: 
$\operatorname{Min}_{\theta, \lambda} \theta_{\mathrm{j}}$,

s.t.

$-\mathrm{q}_{\mathrm{j}}+\left(\mathrm{q}_{1} \lambda_{1}+\mathrm{q}_{2} \lambda_{2}+\mathrm{q}_{3} \lambda_{3}+\mathrm{q}_{4} \lambda_{4}+\mathrm{q}_{5} \lambda_{5}+\ldots+\mathrm{q}_{32} \lambda_{32}\right) \geq 0$

$\theta \mathrm{x}_{1 \mathrm{j}}-\left(\mathrm{x}_{11} \lambda_{1}+\mathrm{x}_{12} \lambda_{2}+\mathrm{x}_{13} \lambda_{3}+\mathrm{x}_{14} \lambda_{4}+\mathrm{x}_{15} \lambda_{5}+\ldots+\mathrm{x}_{132} \lambda_{32}\right) \geq 0$

$\cdots$

$\theta \mathrm{x}_{\mathrm{ij}}-\left(\mathrm{x}_{\mathrm{i} 1} \lambda_{1}+\mathrm{x}_{\mathrm{i} 2} \lambda_{2}+\mathrm{x}_{\mathrm{i} 3} \lambda_{3}+\mathrm{x}_{\mathrm{i} 4} \lambda_{4}+\mathrm{x}_{\mathrm{i} 5} \lambda_{5}+\ldots+\mathrm{x}_{\mathrm{i} 32} \lambda_{32}\right) \geq 0$

$\mathrm{I} 1{ }^{\prime} \lambda_{\mathrm{j}}=1$

$\lambda_{\mathrm{j}} \geq 0$

where:

$\theta_{\mathrm{j}} \quad$ : Technical efficiency of the j-respondent farmer

$\mathrm{j} \quad$ : Respondent farmer, with value of $\mathrm{j}=1, \ldots, 32$

$\mathrm{q}_{\mathrm{j}} \quad$ : Output $(\mathrm{kg} /)$

$X_{i j}$ : The amount of i-input used by the $j$ respondent farmer

i : Input used, with value of $\mathrm{i}=1, \ldots, 4$

$\mathrm{i}=1$ : Polybag input (piece)

$\mathrm{i}=2:$ Seed input (seed)

$\mathrm{i}=3$ : Organic fertilizer input $(\mathrm{kg})$

$\mathrm{i}=4$ : Working hours input (hour)

$\lambda_{\mathrm{j}} \quad$ : Weight of $\mathrm{jth}$ peer farmer

I1' $\lambda_{\mathrm{j}}$ : Convexity constraint to jth respondent farmer

$\theta$ value is a measure of technical efficiency

(TE). The level of efficiency is then analyzed based on the categorization of 3 (three) groups, namely full efficient with an efficiency value equal to 1 , high with a range of efficiency values from 0.900 to 0.999 , and medium with a range of efficiency values of $0.800-0.888$.

Scale efficiency (SE) is obtained by dividing the CRSTE value by the value of VRSTE. If the quotient is equal to 1 , the farmer has scale efficiency and is categorized as Constant Return to Scale (CRS). If the quotient is in the range of $0-<1$ or if there is difference in the two values, the farmer has scale inefficiency (Increasing Return to Scale/IRS or Decreasing Return to Scale/DRS category).

The adjustment of amount of inputs used to achieve full efficient is tested with a radial movement and slack movement. Radial movement is the amount of input deducted from the actual input to achieve full efficient and produce the same output. Slack movement is the maximum amount of input limits that can still be deducted after the radial movement and still produces the same amount of output. Farmers who are not full efficient are only "standardized" to farmers with the same production size and full efficient.

Farmers who become a reference for other farmers are called peers. From the results of peer analysis, information can be obtained about the number of full-efficient farmers who can be peers for farmers who are not full efficient. Other information from the results of this peer analysis is that farmers who are not full efficient can have more than 1 peer. The amount of input reduced can refer to the farmer peers. Peers determine efficient production for farmers. Peer weight is expressed by notation $\lambda$.

\section{Analisis Regresi Tobit}

The Tobit Regression Model is used because the value of the dependent variable, namely efficiency, is limited (censored). The estimation model of factors that influence the level of efficiency is stated as follows:

$\theta=\beta_{0}+\beta_{1} Z_{1}+\beta_{2} Z_{2}+\beta_{3} Z_{3}+\beta_{4} Z_{4}+\varepsilon$

where:

$\theta \quad:$ Technical efficiency

$\beta_{0} \quad$ : Intercept

$\beta_{1} \quad$ : Regression coeficient of age

$\beta_{2} \quad$ : Regression coeficient of education level

$\beta_{3} \quad$ : Regression coeficient of number of family member

$\beta_{4} \quad$ : Regression coeficient of farming experince

$\mathrm{Z}=1$ : Age (year)

$\mathrm{Z}=2$ : Farmer education level

$\mathrm{Z}=3$ : Number of family member (person)

$\mathrm{Z}=4$ : Farming experince (mounth)

The parameters in the model are assumed by the Maximum Likelihood (ML) method using the Eviews program.

a. Simultaneously testing

Hypothesis:

$\mathrm{H}_{0}:$ all $\beta_{\mathrm{i}}=0$

$\mathrm{H}_{1}$ : at least one of $\beta_{\mathrm{i}} \neq 0$

Test statistics:

$\chi_{\text {count }}^{2}=-2 \ln \left(\frac{L_{\text {alternatif }}}{L_{\text {full }}}\right)$

dimana:

$\mathrm{L}_{\text {alternative }}=$ maximum possible value without loading independent variables

$\mathrm{L}_{\text {full }}=$ maximum possible value that contains independent variable

Test criteria:

With significant level $\alpha=0,05$, from Chi-Square Distribution Table with chance of $=1-\alpha(0,05)$ and $\mathrm{dk}=\mathrm{k}$ give result of $\chi^{2}(1-\alpha, \mathrm{k})$ then:

$\mathrm{H}_{0}$ rejected if $\chi_{\text {count }}^{2}>\chi^{2}(1-\alpha, \mathrm{k})$ or if the probability of $\chi_{\text {count }}^{2}<\alpha(0,05)$.

b. Partially testing:

Hypothesis:

$\mathrm{H}_{0}: \beta_{\mathrm{i}}=0$ 
$\mathrm{H}_{1}: \beta_{\mathrm{i}} \neq 0$

Test statistics:

$\mathrm{W}=\frac{\widehat{\beta}_{i}}{S E \widehat{\beta}_{i}}$

where:

$\hat{\beta}_{i}=$ value of variable estimation parameters

$S E\left(\hat{\beta}_{i}\right)=$ standard error

Test criteria:

$\mathrm{H}_{0}$ rejected at level of $\alpha=0,05$ if $\mathrm{W}>\mathrm{t}_{\text {table }}$ or probability value $<\alpha(0,05)$.

\section{RESULTS AND DISCUSSION}

\section{Farming Efficiency Analysis}

The efficiency value of all respondents ranged from

0.816-1 with an average farmer efficiency level of
0.94 or $94 \%$. This means that the average farmer still does not reach technical efficiency. This efficiency value can still be increased by $6 \%$ by adjusting the use of inputs in farming.

The highest number of farmers, namely 16 farmers $(50 \%)$ produced with high efficiency levels (Table 1), with a range of efficiency values of 0.9 0.99 . This means that these farmers can increase efficiency by $1-10 \%$ in the use of inputs. A total of 10 farmers or $31 \%$ of farmers have used fullefficient inputs. Six other farmers (19\%) produced at a moderate level of efficiency with a value range of 0.8-0.89. These farmers can still increase efficiency by $11-20 \%$.

Table 1. Number of farmers based on technical efficiency level

\begin{tabular}{cccc}
\hline Efficiency Range & Efficiency Category & Number of Farmer & Percentage (\%) \\
\hline $0,80-0,89$ & Medium & 6 & 19 \\
$0,90-0,99$ & High & 16 & 50 \\
1 & Full efficient & 10 & 31 \\
\hline Total & & 32 & 100 \\
\hline
\end{tabular}

Source: Data Processed (2018)

Farmers at high and medium efficiency levels have not used full-efficient inputs yet. This is possible because farmers have not met the determined procedures in using the amount of fertilizer and seeds for each polybag used. Another possibility is that the cause of incomplete full efficiency is related to the effectiveness of the length of time in farming. Activities in farming, especially in plant care have not been carried out effectively.

\section{Farming Scale Efficiency Analysis}

Farmer scale efficiency is the ratio obtained from the comparison between the efficiency of CRS and the efficiency of VRS. The results of scale efficiency analysis ranged from 0.928 to 1.000 . The complete

Table 2. Farming scale efficiency distribution

\begin{tabular}{|c|c|c|c|c|c|c|c|c|}
\hline \multirow[t]{3}{*}{$S E$} & \multicolumn{6}{|c|}{ Efficiency Range } & \multirow{2}{*}{\multicolumn{2}{|c|}{ Total }} \\
\hline & \multicolumn{2}{|c|}{$0,800-0,899$} & \multicolumn{2}{|c|}{$0,900-0,999$} & \multicolumn{2}{|c|}{1} & & \\
\hline & $\mathrm{F}$ & $\%$ & $\mathrm{~F}$ & $\%$ & $\mathrm{~F}$ & $\%$ & $\mathrm{~F}$ & $\%$ \\
\hline CRS & 0 & 0 & 1 & 3 & 4 & 13 & 5 & 16 \\
\hline IRS & 3 & 9 & 9 & 28 & 5 & 16 & 17 & 53 \\
\hline DRS & 2 & 6 & 7 & 22 & 1 & 3 & 10 & 31 \\
\hline Total & 5 & 16 & 17 & 53 & 10 & 31 & 32 & 100 \\
\hline
\end{tabular}

Source: Data Processed (2018)

distribution is shown in Table 2. Of the 32 farmers, 5 farmers $(16 \%)$ have a SE value equal to $1(=1)$ or have scale efficiency and operate in constant return to scale. A total of 27 farmers $(84 \%)$ have SE values less than 1 or have scale inefficiency and operate on Increasing Return to Scale / IRS or Decreasing Return to Scale/DRS.

The number of farmers who produce at CRS is 5 people (16\%). Farmers at CRS business scale do not need to reduce or expand the size of their farms. This is due to an increase in the use of inputs which results in an increase in output with the same amount or the proportion of additional inputs equal to the addition of output. 
The largest number of farmers operate at IRS, which is as many as 17 farmers $(53 \%)$, where an increase in the use of inputs will result in an increase in output with a greater amount than the addition of inputs. Farmers at IRS can add amount use of inputs to their farming because they will provide a higher proportion of production compared to the proportion of additional inputs. Farmers can still increase production and expand their farming by adding inputs used.

Farmers who produce at DRS are as many as 10 farmers (31\%) with less suitable use of inputs so that they can reduce production. If farmers increase the use of inputs, it will result in an increase in output with a smaller amount compared to the addition of inputs. Therefore, these farmers can improve technical efficiency by reducing the size of production through reducing input used in production.
Adjustment of the inputs amount to achieve full efficient technically can be seen from analysis result of radial movement and slack movement. Radial movement shows the reduction in input that can be done from the amount used actually by maintaining a fixed amount of output and is at full efficient. The slack movement shows a further reduction in input that farmers can still do after the radial movement and remain at full efficient.

By obtaining values from the radial movement and slack movement, this states that there are farmers who need to adjust the amount of inputs used because these farmers have not used inputs efficiently in farming. Some farmers need to reduce the amount of inputs used in producing the same amount of output. The results of a brief analysis for farmers who have not yet achieved full efficiency can be seen in Table 3 .

\section{Radial Movement and Slack Movement Analysis}

Table 3. Radial movement and slack movement of output and input

\begin{tabular}{|c|c|c|c|c|c|c|c|c|c|c|c|}
\hline \multirow[t]{2}{*}{ Farmer } & \multirow[t]{2}{*}{ VRSTE } & \multicolumn{2}{|c|}{ Output (kg) } & \multicolumn{2}{|c|}{ Polybag (piece) } & \multicolumn{2}{|c|}{ Seed (seed) } & \multicolumn{2}{|c|}{ Organic Fertilizer (kg) } & \multicolumn{2}{|c|}{ Working Hour (hour) } \\
\hline & & RM & SM & $\mathrm{RM}$ & $\mathrm{SM}$ & $\mathrm{RM}$ & SM & RM & SM & $\mathrm{RM}$ & SM \\
\hline 1 & 0,936 & 0 & 0 & -31 & 0 & -929 & -358 & -44 & 0 & -5 & 0 \\
\hline 4 & 0,947 & 0 & 0 & -25 & 0 & -808 & -405 & -43 & 0 & -5 & -6 \\
\hline 7 & 0,868 & 0 & 0 & -63 & 0 & -1.901 & -228 & -91 & 0 & -11 & 0 \\
\hline 9 & 0,862 & 0 & 0 & -88 & -26 & -2.469 & 0 & -176 & -104 & -17 & -2 \\
\hline 11 & 0,930 & 0 & 0 & -56 & -6 & -1.563 & 0 & -112 & -23 & -10 & 0 \\
\hline 12 & 0,950 & 0 & 0 & -40 & -20 & -1.200 & -1.855 & -57 & 0 & -7 & 0 \\
\hline 14 & 0,889 & 0 & 0 & -71 & 0 & -2.263 & -750 & -121 & 0 & -14 & -6 \\
\hline 15 & 0,944 & 0 & 0 & -27 & -4 & -856 & -1.413 & -46 & 0 & -4 & 0 \\
\hline 16 & 0,946 & 0 & 0 & -43 & -5 & -1.216 & 0 & -87 & -18 & -8 & 0 \\
\hline 18 & 0,906 & 0 & 0 & -45 & -18 & -1.355 & -827 & -65 & 0 & -8 & 0 \\
\hline 19 & 0,907 & 0 & 0 & -74 & -11 & -2.077 & -76 & -148 & -361 & -13 & 0 \\
\hline 20 & 0,861 & 0 & 0 & -67 & 0 & -2.001 & -79 & -114 & 0 & -12 & 0 \\
\hline 21 & 0,816 & 0 & 0 & -118 & 0 & -3.772 & -609 & -202 & 0 & -23 & -1 \\
\hline 22 & 0,881 & 0 & 0 & -115 & 0 & -3.665 & -1.574 & -196 & 0 & -22 & -4 \\
\hline 23 & 0,943 & 0 & 0 & -45 & -14 & -1.359 & -1.695 & -91 & -389 & -8 & 0 \\
\hline 24 & 0,933 & 0 & 0 & -32 & 0 & -1.024 & -385 & -55 & 0 & -10 & -52 \\
\hline 25 & 0,946 & 0 & 0 & -52 & 0 & -1.659 & -3.530 & -74 & 0 & -11 & -23 \\
\hline 26 & 0.952 & 0 & 0 & -38 & -15 & -1.143 & -1.737 & -76 & -396 & -7 & 0 \\
\hline 28 & 0,939 & 0 & 0 & -58 & 0 & -1.748 & -1.716 & -83 & 0 & -11 & 0 \\
\hline 29 & 0,903 & 0 & 0 & -93 & 0 & -2.613 & 0 & -187 & -229 & -19 & -20 \\
\hline 31 & 0,908 & 0 & 0 & -73 & 0 & -2.347 & -1.920 & -147 & -308 & -14 & 0 \\
\hline 32 & 0,923 & 0 & 0 & -49 & 0 & -1.583 & -1.630 & -71 & 0 & -10 & -6 \\
\hline \multicolumn{2}{|c|}{ Average } & 0 & 0 & -59 & -5 & -1.798 & -945 & -104 & -83 & -11 & -5 \\
\hline \multicolumn{12}{|c|}{$\begin{array}{l}\text { Source: Processed Data (2018) } \\
\text { Note: }\end{array}$} \\
\hline $\begin{array}{l}\mathrm{RM} \\
\mathrm{SM}\end{array}$ & \multicolumn{11}{|c|}{ : Radial Movement } \\
\hline
\end{tabular}

The average value of radial movement for polybag is 59 pieces, for seeds is 1,798 seeds, fertilizer is $104 \mathrm{~kg}$, and for working hours is 104 hours. The averagevalue of slack movement for polybags is 5 pieces, for seeds is 945 seeds, fertilizer is $83 \mathrm{~kg}$, and working hours is 5 hours. By summing the average value of the radial movement and slack movement, the average value of the polybag input is obtained by 64 pieces, seeds of 2,743 seeds, fertilizer amounting to $187 \mathrm{~kg}$, and working hours is 16 hours.

Each farmer can reduce the amount of inputs used by referring to the results of calculating radial movement and slack movement from the original value. By reducing the amount of input used, farmers will reach the full efficient level. By carrying out further calculations, it can be seen that the average projected value for polybag 
input is 595 pieces, 17,434 seeds, $981 \mathrm{~kg}$ fertilizers, and 109 hours working hours.

\section{Farming Peers Analysis}

Farmers at full efficient level are farmers with the best performance in allocating input use. The farmer can be used as a peer or comparator for other farmers who still have not reached full efficient. The level of efficiency is improved by decreasing the amount of input used..

The highest peer count based on peers analysis is 19 for the 27 th farmer. This means that the 27 th farmer can be referred to by 19 other farmers who are not full efficient. The characteristics of the 27 th farmer are based on the production and amount of use of inputs, namely producing $72 \mathrm{~kg}$ with an area of $60 \mathrm{~m}^{2}$, polybags used as much as 960 , with the amount of organic fertilizer as much as $1,371 \mathrm{~kg}$, seeds as much as 26,880 seeds, and working hours spent on farming is 188 hours. With the land area owned, these farmers can only be referred to by other farmers who have sufficient land. For farmers with a narrower land area, they can refer to other peers with land area as they have.

The results of subsequent peers analysis with various groups using different polybags are shown in Table 4. From this table, it can be seen that peer count of farmers who are full efficient, farmer characteristics, amount of production produced, and total use of production factors.

Table 4. Number of peer counts, production, farmer characteristics, and use of production factors

\begin{tabular}{|c|c|c|c|c|c|c|c|c|c|c|}
\hline Farmer & $\begin{array}{c}\text { Peer } \\
\text { Count }\end{array}$ & $\begin{array}{c}\text { Production } \\
(\mathrm{kg})\end{array}$ & $\begin{array}{c}\text { Age } \\
\text { (year) }\end{array}$ & $\begin{array}{c}\text { Education } \\
\text { Level }\end{array}$ & $\begin{array}{c}\text { Number } \\
\text { Family } \\
\text { Member } \\
\text { (person) }\end{array}$ & $\begin{array}{c}\text { Experience } \\
\text { (month) }\end{array}$ & $\begin{array}{c}\text { Polybag } \\
\text { (piece) }\end{array}$ & $\begin{array}{c}\text { Fertilizer } \\
(\mathrm{kg})\end{array}$ & $\begin{array}{c}\text { Seed } \\
\text { (seed) }\end{array}$ & $\begin{array}{c}\text { Working } \\
\text { Hour } \\
\text { (hour) }\end{array}$ \\
\hline 2 & 9 & 22,5 & 22 & 3 & 2 & 29 & 320 & 457 & 9.600 & 55 \\
\hline 5 & 0 & 22,5 & 30 & 3 & 3 & 52 & 320 & 457 & 9.600 & 62 \\
\hline 6 & 0 & 22,5 & 38 & 3 & 5 & 55 & 320 & 549 & 10.240 & 65 \\
\hline 8 & 12 & 25,0 & 38 & 2 & 3 & 39 & 320 & 549 & 10.240 & 70 \\
\hline 10 & 8 & 22,5 & 37 & 3 & 4 & 55 & 320 & 640 & 9.600 & 60 \\
\hline 13 & 0 & 21,5 & 45 & 1 & 6 & 55 & 320 & 549 & 10.240 & 67 \\
\hline 3 & 5 & 35,0 & 50 & 1 & 4 & 55 & 480 & 686 & 14.400 & 93 \\
\hline 17 & 4 & 60,0 & 36 & 2 & 5 & 17 & 800 & 1.600 & 22.400 & 157 \\
\hline 27 & 19 & 72,0 & 28 & 3 & 2 & 29 & 960 & 1.371 & 26.880 & 188 \\
\hline 30 & 6 & 73,0 & 40 & 3 & 4 & 52 & 960 & 1.920 & 30.720 & 184 \\
\hline
\end{tabular}

Source: Processed Data (2018)

With regard to the number of polybags used, it can be known that full-efficient farmers can be used as a reference for other farmers based on the highest number of peer counts. The reference farmers with polybags as many as 320 are the 8 th farmers. For the use of polybags as many as 480 pieces, the reference farmer is the 3rd farmer. The 17th farmer can be used as a reference for farmers with 800 polybags, and the 27 th farmer is a reference for farmers with a total of 960 polybags. The input used by the reference farmers varies, but the working hours spent in farming have the highest amount.

\section{Analysis of Factors Affecting Farming Efficiency}

Analysis of factors that influence farming efficiency is done by using Tobit regression. Efficiency data is obtained from the efficiency value of the DEA results. The level of efficiency of organic water spinach farming is inseparable from the factors that influence it. Apart from differences in the use of technical inputs, other factors such as age, education level, number of family members, and organic farming experience also affect the level of efficiency. The results of the Tobit regression analysis are shown in Table 5.

The regression equation obtained from the results of the analysis is as follows.

$$
\begin{aligned}
\theta= & 1,03-0,003145 \mathrm{Z}_{1}-0,013683 \mathrm{Z}_{2}+0,009033 \\
& \mathrm{Z}_{3}+0,000876 \mathrm{Z}_{4} .
\end{aligned}
$$

The simultaneous test results using the likelihood ratio obtained by prob. values amounting to 0.0422 which is smaller than the value of $\alpha(0.05)$. This shows that simultaneously all the independent variables analyzed affect the technical efficiency of the use of production factors significantly. The partial test results show that the independent variables that significantly affect technical efficiency are age and experience of farming based on prob. values which is smaller than $\alpha(0.05)$. 
The coefficient of age variable $\left(Z_{1}\right)$ is negative. This means that age has a negative influence on the level of efficiency. The higher the age of the farmer to the age limit of 60 years, the lower the level of efficient farming will be carried out. The age of

Table 5. Result of farming Tobit regression analysis Dependent Variable: EFISIENSI

Method: ML - Censored Normal (TOBIT) (Newton-Raphson / Eviews legacy)

Sample: 132

Included observations: 32

\begin{tabular}{ccccc}
\hline Variable & Coefficient & Std. Error & Z-Statistic & Prob. \\
\hline \hline AGE & -0.003145 & 0.001163 & -2.704534 & 0.0068 \\
EDUCATION & -0.013683 & 0.012799 & -1.069067 & 0.2850 \\
NFM & 0.009033 & 0.009475 & 0.953292 & 0.3404 \\
EXPERIENCE & 0.000876 & 0.000413 & 2.120559 & 0.0340 \\
C & 1.033202 & 0.069722 & 14.81890 & 0.0000 \\
\hline \hline & Value & df & Probability & \\
Likelihood ratio & 9.896907 & 4 & 0.0422 & \\
Source: Processed Data (2018)
\end{tabular}

These results are in line with the results of the research by Binam (2005) and Lubis (2014) which state that with the increase in the age of the farmer the ability to work, fighting power, the desire to take risks and the desire to implement new innovations are also diminishing. Younger farmers will find it easier to receive information and understand new farming practices, which will increase the level of technical efficiency.

The coefficient of experience variable $\left(Z_{4}\right)$ is positive. This means that the experience variables has a positive influence on the level of farm efficiency. The longer the farming experience, the higher the level of efficient farming will be carried out. Farmers have better understood the practices of organic cultivation by increasing farming experience. The average experience of organic farming from all farmers is 37 months. Farmers who have achieved full efficiency is a total of 10 people, the range of farming experience is 14-60 months.

Several studies in Lubis (2014) state that farmers' knowledge of cultivation increases in line with farming experience. The longer the experience, the more skilled the farmer is in managing farming, having better technology knowledge and adoption skills, having wider networking so that he has the opportunity to obtain information more quickly and also applying the technological information he receives by participating in several extension activities and training. farmers is related to the physical abilities of farmers in carrying out an activity. The average age of farmers is 40 years. Total efficient farmers are 10 people with an age range of 22-50 years.
The age variable gives a more dominant influence than the experience of farming variables. This is based on the regression coefficient of the two variables, namely the age variable (Z1) and farming experience (Z4) in the amount of 0.003145 and 0.000876 . The age variable coefficient has a greater value than the farming experience variable.

Educational level variable $\left(\mathrm{Z}_{3}\right)$ does not significantly influence the level of efficiency. Farmers gain knowledge and skills related to aquaculture practices not based on consideration of education levels but through socialization, training, counseling, and mentoring programs provided by business partners intensively. Therefore, the activity of farmers in these activities is expected to further improve the level of technical efficiency of farmers.

The variable of number of family members $\left(Z_{4}\right)$ also does not affect the level of efficiency. The size of the number of family members does not affect the achievement of farmers' technical efficiency. This is because the farmers work alone without being assisted by other family members. Thus, farmers determine their own use of inputs in farming and are not affected by other family members.

\section{CONCLUSION}

The level of technical efficiency is measured by using Data Envelopment Analysis (DEA) with a 
Variable Return to Scale (VRS) approach. The efficiency value of 32 respondents ranged from 0.864 to 1 . In general, the average efficiency level is 0.94 or $94 \%$. This means that the average farmer still does not reach full efficiency. Farmers can still increase efficiency by $6 \%$ by adjusting the use of inputs. Farmers who are full efficient are 10 people and 22 farmers still don't reach full efficient. Possible causes of not full efficient are the use of inputs that are not in accordance with procedures.

Farmer efficiency can be improved by changing the scale of business. Based on scale efficiency, there are 5 (five) farmers having scale efficiency and operating in constant return to scale. Twenty-seven farmers have scale inefficiency, which consists of 17 farmers operating in increasing returns to scale and 10 farmers operating in decreasing returns to scale.

Radial movement is a reduction in the number of inputs used to achieve full efficient. Slack movement is a further reduction in the amount of input used by remaining in full efficient condition. based on the results of the radial movement and slack movement. The results of radial movement and slack movement can be used by farmers who have not reached full efficient to regulate the number of inputs to achieve full efficiency.

Full efficient farmers with the highest number of peers are the 27th farmer, which is 19 peers. These farmers can be referred by 19 other farmers to be able to cultivate efficiently. Farmers with 320 polybags can refer to the 8 th farmer. For the use of polybags as many as 480 pieces, the reference farmer is the 3 rd farmer. The 17 th farmer can be used as a reference for farmers with 800 polybags, and the 27th farmer is a reference for farmers with 960 polybags.

The results of the Tobit regression analysis show that age and farming experience affect the value of technical efficiency. The coefficient value of the age variable with a negative sign indicates that the age variable has a negative effect on farming technical efficiency. The higher the age of farmers until the age of 60 years, the lower the level of efficient farming. The value of the experience coefficient of organic farming is positive. This means that the variable experience in farming has a positive effect on farming technical efficiency. The longer the farming experience, the higher the level of efficient farming. Age variable has a more dominant influence on technical efficiency than organic farming experience variable.

\section{REFERENCES}

Ariyanti, R. O., Maria dan Priyanto, S.H. (2013). Analisis Before-After Kehidupan Sosial Ekonomi Petani Organik. Fakultas Pertanian dan Bisnis UKSW Salatiga.

Asiah, N., Salmiah, S., Ayu, S. F. (2018). Analisis Efisiensi Penggunaan Pupuk Oleh Petani Pada Tanaman Bawang Merah (Allium ascalonicum L.) Dengan Menggunakan Metode Data Envelopment Analysis (DEA) (Kasus: Desa Tongging, Kecamatan Merek, Kabupaten Karo). Journal On Social Economic of Agriculture and Agribusiness. Vol 9. No. 1.

Asmara, R. (2017). Efisiensi Teknis Usahatani Tanaman Pangan dalam Upaya Peningkatan Produksi: Pendekatan Fungsi Produksi Frontier Stokastik dan Data Envelopment Analysis (DEA). Disertasi. Program Doktor Ilmu Pertanian. Fakultas Pertanian. Universitas Brawijaya. Malang.

Astuti, Puji, Ismono R. Hanung, Situmorang Suriaty. (2013). Faktor-Faktor Penyebab Rendahnya Minat Petani Untuk Menerapkan Budidaya Cabai Merah Ramah Lingkungan Di Kabupaten Lampung Selatan. Jurnal IlmuIlmu Agribisnis, Vol. 1 No. 1.

Badan Penelitian dan Pengembangan Pertanian. (2017. Kawasan Rumah Pangan Lestari KRPL. Kementerian Republik Indonesia.

Badan Pusat Statistik. (2017). Kecamatan Pagelaran dalam Angka. Kabupaten Malang.

(2017). Impor Sayuran Menurut Negara Asal Utama, 2012-2016 (000 $\mathrm{kg})$.

(2017) Persentase Pengeluaran Rata-rata per Kapita Sebulan Menurut Kelompok Barang.

(2017). Produksi Tanaman Sayuran Semusim Menurut Jenis Tanaman (Ton).

(2018). Perkembangan Konsumsi Rumah Tangga per Kapita di Indonesia. Kelompok Sayur-sayuran. Komoditi Kangkung.

Badan Standarisasi Nasional. (2016). Sistem Pertanian Organik. Standar Nasional Indonesia (SNO).

Beattie, B. R., Taylor, C. R., and Watts, M. J. (2009). The Economics of Production. Second 
Edition. Krieger Publishing Company. Florida.

Binam, J.N., Tonye, J., Wandji, N. (2005). Source of Technical Efficiency among Smallholder Maize and Peanut Farmers in the Slash and Burn Agriculture Zone of Cameroon. Journal of Economic Cooperation, 26, 1.

Coelli, T. J., Rao, D. S. P., O'Donnell, C. J., dan Battese, G. E. (2005). An Introduction to Efficiency and Productivity Analysis ( $2^{\text {nd }}$ ed.). Springer Science+Business Media, Inc., United States of America.

Constantin, P.D., Martin D. L., Rivera. (2009). Cobb-Douglas, Translog Stochastic Production Function and Data Envelopment Analysis in Total Factor Productivity in Brazilian Agribusiness. The Flagship Research Journal of International Conference of the Production and Operations Management Society Volume 2, Number 2.

Debertin, D.L. (2012). Agricultural Production Economics. Second Edition. Macmillan (ISBN 0-02-328060-3). University of Kentucky.

Dwiastuti, Rini. (2017). Metode Penelitian Sosial Ekonomi Pertanian. Dilengkapi Pengenalan Metode Penelitian Kuantitatif, Kualitatif, dan Kombinasi Kuantitatif-Kualitatif. UB Press. Malang.

Ekaningtias, Decy dan Daryanto, H. K. S. (2013). Analisis Pendapatan dan Efisiensi Teknis Usahatani Horenso Kelompok Tani Agro Segar Kecamatan Pacet Kabupaten Cianjur Jawa Barat. Forum Agribisnis. Vol 3. No. 1. Departemen Agribisnis, Fakultas Ekonomi dan Manajemen, Institut Pertanian Bogor.

Farrel, M.J. (1957). The Measurement of Productive Efficiency. Journal of the Royal Statistical Society. Series A (General). Vol. 120. No. 3.

Gujarati, D.N., (2003). Basic Econometrics. Fourth Edition. The McGraw-Hill Companies, Inc..

Hidayati, Reny. 2018). Analisis Efisiensi Teknis Usahatani Kubis di Kabupaten Agam, Sumatera Barat. Jurnal Hexagro. Vol. 2. No. 1.

Hirschey, Mark. (2005). Fundamentals of Managerial Economics (Economic Applications Access) [8th ed.]. SouthWestern College Pub.

Lasmini, Fuji, Nurmalina, Rita, dan Rifin, Amzul. (2016). Efisiensi Teknis Usaha Tani Padi Petani Peserta dan Non Peserta Program SLPTT di Kabupaten Sukabumi. Jurnal
Manajemen \& Agribisnis, Vol. 13 No. 1, Maret 2016. P-ISSN: 1693-5853 E-ISSN: 2407-2524.

Lawalata, M., Darwanto, D. H., dan Hartono, S. (2015). Efisiensi Relatif Usahatani Bawang Merah di Kabupaten Bantul dengan Pendekatan Data Envelopment Analysis (DEA). Ilmu Pertanian Vol. 18 No.1.

Lubis, R. R. B., Daryanto A., Tambunan M., dan Rachman, H. P. S. (2014). Analisis Efisiensi Teknis Produksi Nanas: Studi Kasus Di Kabupaten Subang, Jawa Barat. Jurnal Agro Ekonomi. Volume 32 No. 2.

Machmuddin, N., Kusnadi, N., dan Syaukat, Y. (2016). Analisis Efisiensi Ekonomi Usahatani Padi Organik dan Konvensional Di Kabupaten Tasikmalaya. Forum Agribisnis. Vol 6. No. 2. Departemen Agribisnis, Fakultas Ekonomi dan Manajemen, Institut Pertanian Bogor.

Manik, G. H., Asmara, R., Maarthen, N. (2018). Analisis Efisiensi Produksi Usahatani Jagung Menggunakan Data Envelopment Analysis (DEA) Di Desa Maindu, Kecamatan Montong, Kabupaten Tuban. Jurnal Ekonomi Pertanian dan Agribisnis (JEPA) Volume 2, Nomor 3.

Mardliyah, Ainul dan Fathy, Muhammad. (2013). Analisis Efisiensi Usahatani Cabai Merah di Kabupaten Tanggamus. Jurnal Wacana Pertanian. Vol 12 (1).

Marjelita, Lena, Restuhadi, Fajar, dan Yusri, Jumatri. (2015). Analisis Efisiensi Produksi Petani Padi Peserta Operasi Pangan Riau Makmur (OPRM) Di Kabupaten Kampar. Indonesian Journal of Agricultural Economics (IJAE), Volume 6, Nomor 1, Juli 2015, ISSN 2087-409X.

Mayrowani, Henny. (2012). Pengembangan Pertanian Organik Di Indonesia. Pusat Sosial Ekonomi dan Kebijakan Pertanian. Badan Penelitian dan Pengembangan Pertanian. Kementrian Pertanian. Forum Penelitian Agro Ekonomi, Volume 30 No. 2, Desember 2012.

Nurwati, N., Lidar, S. dan Mufti. (2015). Model Pemberdayaan Pekarangan Di Kecamatan Rumbai Pesisir Kota Pekanbaru. Jurnal Agribisnis Vol. 17 No. 1.

Oktafia, L. S, Chalil, D., dan Kusuma, S. I. (2016). Analisis Efisiensi Usahatani Bawang Merah (Allium ascalonicum L.) Di Desa Cinta Dame Kecamatan Simanindo Kabupaten Samosir. Jurnal Universitas Sumatera Utara.

Pasaribu, Agustina, Bakce, Djaimi, dan Dewi Novia. (2016). Analisis Efisiensi Produksi 
Usahatani Kelapa Di Kecamatan Keritang Kabupaten Indragiri Hilir. Jurnal Online Mahasiswa (JOM) Faperta Vol.3 No. 1 Februari 2016. ISSN: 2355-6838.

Pindyck, R. S. and Rubinfeld, D. L. (1997). Microeconomics. Third Edition. Prentice Hall International Inc.

Prayoga, Adi. (2010). Produktivitas dan Efisiensi Teknis Usahatani Padi Organik Lahan Sawah. Jurnal Agro Ekonomi, Volume 28 No.1, Mei 2010: 1 - 19, Print-ISSN: 0216-9053; E-ISSN: 2541-1527.

Semaoen, Iksan. (1992). Ekonomi Produksi Pertanian: Teori dan Aplikasi. Ikatan Sarjana Ekonomi Indonesia (I.S.E.I.) Cabang Jakarta.

Sembiring, Yance Trisnawaty. (2008). Peran Petani Perempuan dalam Pelaksanaan Pendidikan Anak Usia Dini Di Desa Namoriam Kecamatan Pancur Batu. Departemen Ilmu Kesejahteraan Sosial. Fakultas Ilmu Sosial Dan Ilmu Politik. Universitas Sumatera Utara. Medan.

Shinta, Agustina. (2011). Ilmu Usahatani. Universitas Brawijaya Press (UB Press). Malang.

Sholeh, S., Hanani, N., Suhartini. (2013). Analisis Efisiensi Teknis Dan Alokatif Usahatani Wortel (Daucus carota L.) Di Kecamatan Bumiaji Kota Batu. AGRISE Volume XIII No. 3

Soekartawi, Soeharjo A, Dillom, John L., Hardaker, J. Brian. (2011). Ilmu Usahatani dan
Penelitian untuk Pengembangan Petani Kecil. Universitas Indonesia (UI Press). Jakarta.

Suprapto, Edy. (2010). Analisis Faktor-Faktor yang Mempengaruhi Usahatani Padi Organik Di Kabupaten Sragen. Tesis. Fakultas Ekonomi Universitas Sebelas Maret. Program Pascasarjana Magister Ekonomi dan Studi Pembangunan. Surakarta.

Sutanto, R. (2002). Penerapan Pertanian Organik, Pemasyarakatan dan Pengembangannya, P.T. Kanisius, Yogyakarta.

Togatorop, Rodo Berliana Br. (2011). Analisis Efisiensi Produksi dan Pendapatan pada Usahatani Jagung Di Kecamatan Wirosari, Kabupaten Grobogan (Studi Kasus: Di Desa Tambahrejo dan Desa Tambahselo). Ilmu Ekonomi dan Studi Pembangunan, Fakultas Ekonomi, Universitas Diponegoro.

Widarjono, Agus. (2017). Ekonometrika. Pengantar dan Aplikasinya Disertai Panduan EViews. Edisi Keempat. UPP STIM YKPN. Yogyakarta.

Widyawati, A.F. dan Rizal, M. (2015). Potensi Pengembangan Tanaman Sayuran Skala Rumah Tangga Di Samarinda, Kalimantan Timur. Pros Sem Nas Masy Biodiv Indon, Volume 1, Nomor 8. Balai Pengkajian Teknologi Pertanian (BPTP) Kalimantan Timur, Samarinda. 
This page is intentionally left blank 